\title{
Making Change from Below ${ }^{1}$
}

\author{
Dorothy E. Smith University of Victoria
}

\begin{abstract}
Résumé
Dans le présent article, je m'efforce de cerner ce qui, selon moi, entrave les efforts pour induire un changement dans un contexte de capitalisme mondial. Si j'avance la notion de changement par le bas, c'est du fait de la quasi disparition, du fait de la fragmentation de l'État à de multiples niveaux, tant au Canada que sur la scène internationale, du type d'organisation gouvernementale dont il était possible d'envisager de s'emparer. De plus, le lieu de la lutte s'est déplacé, passant de l'immédiatement physique aux relations par l'entremise du texte qui dominent nos sociétés contemporaines. Enfin, nous vivons une réorganisation rapide de la gouvernance, où l'organisation bureaucratique et professionnelle cède la place à de nouvelles formes de gestion qui subordonnent le gouvernement et les institutions publiques, les reléguant au service du capital mondial. Il est toutefois possible de trouver des exemples de changement par le bas s'étant avéré efficace. Je me tourne d'abord vers le mouvement des femmes qui, outre ses succès spécifiques, nous a permis, me semble-t-il, en tant que Canadiennes, d'être reconnues et de nous identifier nousmêmes comme sujets et agents politiques. Je présente ensuite des exemples plus récents de changement amorcé par des organisations non gouvernementales, y compris des syndicats. Outre l'atteinte d'objectifs spécifiques, s'organiser ainsi pour induire un changement est important pour apporter aux gens l'expérience de l'action et de l'organisation, pour tisser des liens entre les militants et pour asseoir la capacité des gens à se percevoir comme sujets politiques.
\end{abstract}

\begin{abstract}
In this paper I've tried to spell out what I think we're confronting in attempting to make change in the context of global capitalism. I've used the notion of making change from below because the kind of government organization that made taking it over appear practicable has largely disappeared in a fragmentation of the state at many levels both within Canada and at international levels. Moreover the terrain of struggle has shifted from the directly physical to the contemporary text-mediated relations that pervade our societies. Right now we are also going through a rapid reorganization of governance replacing bureaucratic and professional organization with new managerial forms that subordinate both government and public institutions to the service of global capital. We can, however, find models of making change from below that have been effective.
\end{abstract}

1 Keynote Address for the Society for Socialist Studies, University of Saskatchewan, Saskatoon, 2007. 
I look first to the Women's Movement, proposing that in addition to the specifics of its achievements, women in Canada are recognized and recognize ourselves as political subjects and agents. I then introduce more current examples of change initiated by nongovernmental organizations, including unions. While specific objectives may be achieved, in the longer run these forms of organizing to make change are also important in building people's experience of acting and organizing, in extending connections among activists, and in grounding people's capacities to experience themselves as political subjects.

\section{Introduction}

In taking up the topic of making change from below, I want first to recognize how deeply we're embedded in historical trajectories that are constantly changing our ways of life and the problems and issues we confront as well as the terrain and objectives of struggle and organization. We're also caught up in a major destabilization of climate brought about by industrialization and capitalism's dynamic and we don't know where that's going to take us or how we are going to be able to respond to it.

Marx wrote his theory in the nineteenth century and things have certainly changed radically since then, but we still have the central dynamic that he located; a dynamic that generates change beyond the intentions of individuals, even of a capitalist class. Working as an institutional ethnographer with other researchers using the same approach, I've become aware of a pace of change in economy, government and public institutions that continues and intensifies. Making change must, in contemporary society, go to work on a terrain constituted by what institutional ethnographers call the ruling relations, that is, relations in which people's doings are coordinated in the technologically multiple forms of text (more on this later). Institutional ethnography specializes in explorations of these regions from the standpoint of people's everyday worlds and lives. As institutional ethnographies have accumulated over the past several years, they have been discovering trajectories of change within these relations. Such studies register how our everyday lives are being reorganized in, and by, social relations outside our direct and local knowledge.

I want to argue for the potentialities, in contemporary North America, of making change from below. I don't claim such changes can be revolutionary in the sense of overturning a capitalist mode of production in one fell swoop through the seizure of state power - along the lines of the Russian Revolution (or least how it appeared). In our time and in countries like Canada, who can see how such a transformation could come about? Marx and Engels had seen in the social relations of production of their day the possibility of realizing a society in which the actualities of people's generalized interdependence in producing their subsistence could become the basis of a new social form. For them, that potentiality was already present in the existing relations of production; all that was needed was that one move, divesting capitalists of ownership of the means of production, a move that required 
the seizure of state power and the establishing of democracy through which the working class, the class of producers, would take power.

But capitalism has since their time been transformed as the technologies of text, print, film, radio, television, and finally the violently expanding forms of electronic technologies, have detached organization and the social forms of consciousness ${ }^{2}$ from the local particularities of person and place. Here are the ruling relations, coordinating people's doings translocally. True, the relations coordinated by the exchange of money and commodity were themselves already translocally organized, but they remained relations among particular individuals, situated in definite local settings until this more recent transformation, one that is outside Marx's historical experience. As the text-mediated forms of capital and management were generalized and objectified towards the end of the nineteenth century, capitalism began to develop the capacities for operating that can now be recognized in the more elaborated development we call globalization.

What's less visible is the fragmentation of that apparently unitary object, the state, that once socialists thought we might get hold of. Of course, unlike the United Kingdom where the centralization of national government made it possible for Margaret Thatcher to reorganize local governments resistant to her neoliberal revolution, the Canadian state is already dispersed among federal, provincial and municipal levels - and in some provinces such as Ontario counties. Beyond national government are further and higher through fragmentary levels of governance: a United Nations, a World Bank, an International Monetary Fund (IMF), a G-8, an International Court of Justice, a World Trade Organization (WTO), and so on. Most of these, such as the IMF, function without accountability to an electorate or with an accountability so indirect as to amount to nothing. The director of the IMF, writes Larry Elliott (2007:18), is one of "a select band of men wielding enormous power beyond the scope of the democratic process." He has the capacity to "lay down the financial law to poor countries in Africa .. .without the approval of a single voter anywhere in the world" (Elliott: 18). This 'select band' includes the World Bank and the World Trade Organization among others.

In theory these guys are tribunes of the people. They are put there after horsetrading by national governments to pursue policies that will ensure global peace and prosperity. They embody a distinct world view; growth is good, inflation is bad; free trade is good, protection is bad; free movement of money is good, capital controls are bad; the market is good, the public sector is bad (Elliott, 2007: 18 ).

These international powers intervene directly and indirectly in government at the national level, sometimes bypassing national and regional governmental bodies to intervene directly

2 In The German Ideology, language is identified as a social form of consciousness (Marx and Engels, 1970). 
in the operation of public institutions - an example is the World Bank's initiatives to change university administration in the Western world to one which recognizes corporations as clients, faculty as employees, and students as customers (CAUT/ACPPU, 1998). With such dispersal and interpenetration of governing functions at both national and international levels, making the kinds of changes socialists have striven for can no longer be achieved by simply taking over government. Hence the increasing relevance of making change from below.

\section{Ruling Relations and the Changed and Changing Terrain of Struggle}

The changing organization of government is not all we confront in making change. There are changes that go historically deeper. The forms of governance that now rule us exist in the text-mediated mode that institutional ethnographers have come to know as the ruling relations (Smith, 1999). Let me be clear first of all that in identifying ruling relations, we're not adding yet another entity to the contemporary multi-conceptual array of state, government, governance, hegemony, corporation, large-scale organization and so on. Rather the concept of the ruling relations directs attention to the mode in which these forms of social organization actually exist, that is, as people's activities, our work, is coordinated by texts. As implied above, the term text is understood inclusively to locate any material thing carrying words, numbers or images that can be and is replicated in multiple copies so that the consciousness of anyone looking, reading, hearing, is coordinated (though not determined) by the same words, numbers, images, or sounds as any other.

Printed texts have been historically the major coordinating mode through which objectified forms of consciousness come into historical being. The invention of moveable type and of the then rapidly realized ability of print to replicate multiple copies of the same text and hence fully to detach words and images from face-to-face engagement among particular people has over time introduced radical changes in how society is organized. Law has come to rely on fact rather than on the credibility of witnesses and authorities (Shapiro, 2000). The very existence of facts is an historical product of the accelerated distribution of print and so is the emergence of the differentiated genres of fiction, history and news (McKeon, 1987). The material base of public discourse, Habermas's (1992) public sphere is to be found originally in print - journals, newspapers, newsletters, and the like.

In the latter part of the nineteenth century, new objectified forms of organizing people's work based in replicable texts emerged within the ruling relations. They can be found earlier in government bureaucracies, but in the late nineteenth and early twentieth centuries, corporations were developed into a form of organizing that separated ownership in the form of stocks and shares from the direct management of corporate operations (Berle and Means, 1932). Advances in the speed and range of communications and transportation intersected with the evolution of new corporate forms capable of managing operations 
across multiple local sites. Associated with this new mode of organizing capital were other expansions of the ruling relations. Government at all levels adopted bureaucratic forms of administration. Technological innovations both enabled and required specialized and standardized training, marketable as professional qualifications. Colleges, universities, and public schools grew in size and complexity, responding to the largely middle-class demand for qualifications at various levels and, more generally, to the need for a more literate and numerate labour force. And later in the twentieth century came the radicalizing technologies of radio, film, television and computers.

The predominance of ruling relations in contemporary societies as the mode in which power exists means a radical change in the terrain of struggle. Contrast this terrain with how it has been in the past before the ruling relations grew in extent and complexity and took on the dominating role they play today. Take the Peasants' Revolt in late fourteenth century England. Led by a man called Wat Tyler, men marched on London, attacked and captured the Tower of London, killed some bishops and lords, negotiated with the young king who conned them into believing he'd respond to the injustices they were experiencing. Most went home; some stayed, including their leader. Those who stayed were massacred (Bobrick, 2001). I'm not concerned with the failure of the revolt but with how it was carried out. The notion of a terrain of struggle here becomes literal rather than metaphorical. The men walked; perhaps some rode. They physically assaulted a fortress built to withstand assault and captured it. They killed some of those who oppressed them and their leaders were in their turn killed. If they had been able somehow to seize power as later in England did the forces led by Oliver Cromwell, they would have governed in the same fashion. But contemporary struggles against oppression are conducted, at least in part, on the terrain of the ruling relations. Even the notion of struggle takes on a metaphorical character.

By the early nineteenth century England, government had begun to take on a different form. There was government by law. The organized working class was, in some cities, able to capture and take control of sectors of local government such as the police and the implementation of the Poor Law (Foster, 1974). In the mid-nineteenth century, Marx and Engels could envisage the potential of working class takeover of city government and diagnosed its failure to do so after establishing the Paris Commune as resulting from yielding the dominant position in the new governmental process to the petty bourgeoisie. Though the ruling relations, particularly those that organize social consciousness via the medium of texts had already emerged, they had not yet entered substantially into the organization of government, let alone of capital. They had not as yet matured into the powerful presence they have come to have in our time. Marx did not encounter the objectified forms of organization and objectified social consciousness that coordinate contemporary society; they were not part of his world and did not, therefore, enter into his conceptual grounding (Smith, 2004). We, however, confront a very different terrain of struggle than 
that of his time. Contemporary governments wouldn't be accessible to takeover in those ways: they exist in documents: in legislation in a distinctive institutional language, in textually-mediated hierarchic intersections of different levels of governments; in the laws that enable them to extract taxes; in the text-mediated administrative apparatuses that do the work of collecting taxes, directing and administering sources and objectives of funds, maintaining order at various levels, collecting garbage, maintaining public health, and so on and so on. Indeed they exist only in the work coordinated by texts; both of those who do the work of governance and those who participate in being governed. More than that, the textual modes in which capital now exists also deny the earlier objective of seizing ownership from capitalists. The complex of the ruling relations are the site of multiple institutional forms including those, as I'll emphasize later, that are geared to make change on the terrain of the ruling relations.

Here is the region that institutional ethnography explores from the standpoint of people's everyday experience of how it enters into and shapes our lives. Though each institutional ethnography takes up a particular issue for people that arises in their everyday lives and focuses on specifically relevant aspects of the institutional relations, the accumulation of ethnographies provides a widening and deepening knowledge of how the ruling relations operate in contemporary Western society, particularly, though not exclusively, in North America. One distinctive aspect of how institutional ethnography works is in tracing social relations and organization beyond what is immediately observable by recognizing texts as coordinating sequences of people's work (Turner 1995; 2003). The recognition of texts, as organizers, is of primary importance in explorations that reach beyond the local and particular of people's everyday experience. Institutional ethnography is a sociology specializing in the same terrain of ruling relations in which efforts to make change must go forward.

\section{Making Change from Below and the Women's Movement}

Institutional ethnography came out of the Women's Movement as a method of inquiry that took up problems arising for people in the ruling relations. Indeed, the very concept of the ruling relations was invented to name the extra-local relations that women's standpoint in our everyday lives began to make visible. The Women's Movement was notably one that initiated and effectively made change within the ruling relations from below.

There's really nothing new about people making change from below. There are many examples. But in contemporary society, the making of change involves participating in the ruling relations and getting them to work for those who organize and act from below because they have no alternative. We can look back to the beginnings of the ruling relations in the region of public discourse. Working class consciousness in Britain was textually mediated. Printed texts - pamphlets, newsletters, journals as well as books - informing 
and conceptualizing the state of class oppression were distributed to many, many local sites where working people came together in pubs or clubs to listen to the autodidacts (Rose, 2002) read the latest news, or pamphlet, or from the political thinking of such as Tom Paine. I imagine, mid-century, Marx's and Engels's Communist Manifesto might have traveled among working class people in Britain in just such ways. In the early twentieth century International Workers of the World representatives read Marx to unemployed workers in camps close to the main railroads. Class consciousness wasn't just in people's heads, it was a discourse, a community organized by what Smith and Schryer (2007) have called floating texts (i.e. a community that is connected primarily through the medium of texts and not necessarily through face-to-face relations). Hence class consciousness was a material process developing under the actual conditions of skills, transportation, printed materials, and local networks. Shared experiences in the workplace could be interpreted in common terms - a shared discourse. Over the nineteenth century in Britain, the working class became the basis of organization at local and national levels, gaining universal manhood suffrage (women did not get the vote in Britain until the twentieth century), passing legislation prohibiting child labour, and securing rights to organize, an eight-hour day and many other gains. It was a long struggle but let's not underestimate the achievements even though its outcomes have been, and are now, being undermined.

Once we begin carefully to examine gains made by marginalized or oppressed groups, we can see more and more the importance of making change from below. My own experience of making change from below was as an activist in the Women's Movement. It taught me how common conditions of oppression could become the basis of a movement that spread from local site to local site rapidly and without the type of political organization that socialists generally see as essential. An extraordinarily rapid transformation of consciousness arose in multiple sites almost simultaneously and, of course, the medium was textual sometimes even the inadvertent outcome of regular news stories of some initiative taken by women as women instructed others not only in the actualities of oppression but also in the possibilities of struggle. Books such as Kate Millett's Sexual Politics (1970) gave us the concept oppression and taught us to apply it to ourselves. They showed us how we had as women no alternative to positioning ourselves as male subjects in the cultural, political and intellectual life of our societies. In British Columbia where I was employed at the time, feminists, myself included, traveled all over the province to talk with groups of women of very varied backgrounds and situations - in communities, in trade unions, at colleges, as well as at universities. All of us were discovering and struggling to exercise our right, our authority - our authority - to speak as women and to learn from each other about the issues, problems, and oppressions of our everyday lives. I imagine this to have been a process analogous to that in which working class consciousness emerged in early nineteenth century Britain. It was faster, because communications were faster, but essentially the same knitting of shared experiences of oppression with a common discourse in which the 
conditions of change and making change, could be envisaged.

Of special relevance here are the struggles that focused specifically on the textual dimensions of the ruling relations and that have largely eliminated the earlier exclusion (or segregation in women's magazines, women's books, etc.) of women from being recognized as subjects and agents in intellectual, cultural and political life. I have emphasized above the significance of the texts of public discourse in the organization of the Women's Movement. The movement generated its own - media were created; songs were written; books appeared; university and college courses on, and given by women, were started. Gender was incorporated into the Charter of Rights and Freedoms. We learned to name battered women (Walker, 1995) and then to move to institutionally recognizable forms such as domestic abuse. Issues of pay equity and of the proportion of women in the positions of power were raised. Organizations supporting immigrant women were created. Marital property rights were radically modified. This list is only a small part of what was achieved. All such changes were made by initiatives from below and within the ruling relations.

The changes made were many and were made piece-by-piece, adding up to a significant overall change in women's status in Canadian society. And in almost every situation and every outcome, the making of change involved participating in the ruling relations and making changes in how they were organized. The most general, least noticed, and most lasting change was in the status of women as political subjects; we became recognized and could recognize one another as having the authority of our own voices as women. The relative invisibility of the Women's Movement's achievements is a testimony to its effectiveness. What has been achieved in Canada can be forgotten because it is built into the ruling relations and can be taken for granted.

At the same time, it is important to note a difference between the organization and successes of the Women's Movement and those of the nineteenth century working class movement. The political coherence and unity of organized struggle that characterizes the latter were based on communities of local experience of exploitation in newly industrializing workplaces. This shared basis in working class people's experience of capitalism consolidated political objectives; it is presupposed in Marx and Engels's call to the working class to unite for workers "have nothing to lose but their chains" (1988: 28). But though women in the 1970s and 1980s could agree on issues of exclusion and voice, once we had been able to recognize women's voices as authoritative (at least for ourselves), we had many different issues to take up. Lesbians challenged heterosexual women, nonwhite women challenged white women's racism (there were African-Canadian women who confronted the pro-choice movement accusing it of genocide), women in trade unions struggled for the recognition of issues of special concern to women, and First 
Nations women undertook struggles within their communities where, it could be argued, contemporary forms of patriarchy had emerged with the imposition of colonialism on their people. Organizations were also differentiated institutionally - women's health, our status in universities and colleges, access to training in law and medicine, women teachers' access to administrative positions in schools and school boards, and many others. The Women's Movement displayed a fragmentation arising from the multiple foci of concern and interest arising for women in contemporary society. Attempts to impose unity never survived. And, indeed, in my view, the expansion of the Women's Movement as well as its more radical manifestations arose from the ability of the category woman to unleash difference. Once we broke with silence, the movement did not coalesce; organization emerged, and a diversity of issues was taken up.

Divergences, criticisms, quarrels, were powerful in the expansion and development of the movement. Woman was never and could not be a homogeneous category. Once the door had been opened, it flew wide and many different problems, critiques, oppressions, came bursting through. Women's exclusion from the making of the political, organizational, institutional and cultural life of the society was so complete at the outset of this phase of a long historical struggle that there was virtually no part or aspect of the society in which women were present that could not generate its distinctive issues and bases of struggle. The changes that were made were always being made from below. Making change from below was itself a generator of consciousness as women came together, worked together to make change and saw that indeed change could be made.

\section{The Changed and Changing State}

Changes made from below by the Women's Movement were largely made in, and through, relations with various levels of government and with, and within, public institutions universities and colleges were a particular focus. More equitable access to professions such as law and medicine were important, and achieved, objectives. Women were also active in trade unions and still are. But the Women's Movement never meshed successfully with the various Marxist movements of the same period. In contrast with the diversities generated in the Women's Movement, each Marxist organization of the same period claimed ideological authority; they were differentiated and preserved their differences ideologically. The dialectic of ideological quarrels were, unlike the quarrels of the Women's Movement, unproductive. They shared with the general political movement of socialism a focus on the national state as their objective. And, indeed, in the 1970 s and early 1980s, the period of greatest activity in the Women's Movement, it still seemed to socialists that an economy could be reshaped within the scope of a nation-state. Hence, gaining control of the national government was a major objective.

In those days, Keynes's model of the workings of a national economy seemed a reasonable 
representation of the interconnections and mutual interdependence of capital, wages, spending, savings and investment, all within one nationally defined territory. But this model doesn't hold any more (though it may, of course, for the global economy as a whole). Here, however, rather than globalization as such, I'm bringing into focus the displacement of the national state as a locus of economic management. The circuits that Keynes modeled no longer operate at the national level. Corporations with a home base in one country may operate with multiple sites of production under different national governance; the manufacture of a given product may be coordinated in several national sites, and services may be provided transnationally (the combination of rapid technological innovations with corporate cost-saving ingenuities makes it hard to see just where we're going). The whole organization of accountability within a national economy in which the interests of capital could be negotiated with the interests of working class people (this was the basis of the capital-labour deal in Sweden as long as it lasted) has come apart. Low wages, long working hours without overtime pay, and poor working conditions reduce costs of products without their effects becoming visible in the reduction of consumers' ability to buy. And if there is trouble from labour organization, government taxes, or government environmental regulation in one place, it's become all too easy for capital to just pick up and move or threaten to do so.

The restructuring of government and public institutions that has been going forward since the 1980 s is sometimes identified with neoliberalism. Institutional ethnography, however, aims always at recognizing the material actualities of people's actual doings and how they are coordinated when addressing forms of social consciousness such as ideologies. Ideologies are specific ideas, concepts, theories, claims to knowledge that are entered into public text-mediated discourse in its material forms - mass media, book publications, and so on. Neo-liberalism has academic bases in the economic theories of such as Milton Friedman. It has been popularized and disseminated by an institutional complex of rightwing organizations - thinktanks, foundations, consultants, and so on - that were established during the 1980 s to create a neoliberal alternative to the counterculture movements of the 1960s and 1970s. This institutional complex has been massively funded. Between 1992 and 1994, \$80 million dollars US funded eighteen conservative thinktanks in the United States (Messer-Davidow, 2002). Lewis Lapham (2004) notes that in 2001 nine leading conservative foundations had $\$ 2$ billion dollars (US) in assets and twelve conservative thinktanks disposed of more than a $\$ 100$ million dollars US. In addition, he reports $\$ 300$ million dollars (US) was expended on what he calls the "conservative message machine" (Lapham, 2004: 37) such as Fox News Channels conversation TV. I don't know of comparable studies for Canada but we have only to look around to recognize some of the same active and material initiatives transforming Canadian political culture in the conservative media originating in Conrad Black's newspaper empire or of the influence of thinktanks such as the Fraser Institute, or the cultural initiatives of the not-for-profit Conference Board of Canada. 
We have indeed been going through a revolution mediated by the state, but it has been a revolution instigated by a capitalist class and it's been sneaky, piece by piece, a small change here, another there. Neoliberalism displaces the concept of the collective or public good embedded in traditions of political thinking since the nineteenth century. Margaret Thatcher did in that concept when she declared that "society does not exist" - perhaps the sharpest and most succinct statement of neo-liberalism. This new ideology of state governance asserts that there are only individuals - individuals who are free to make choices for themselves and must bear responsibility for their own choices and their own lives. It is spread around, it gets worked up as policy, it gets technically developed by such agencies as the international firms of accountants, and it gets specified for governments and public institutions. Nancy Naples (1997) describes a congressional hearing on welfare in 1987-88 in which neoliberal ideology gets specified as welfare relevant categories. Conflating the ideology of neo-liberalism with the organization of state and institutions that have been developed from, and legitimated by it, obscures the actualities of a major reorganization of the state at all levels, progressively penetrating public institutions such as health care and education, including universities and colleges.

A major institutional specification of neoliberalism in Canadian government is described as the new public management (Aucoin, 1995; Shields and Evans, 1998; McCoy, 1998; 1999; McBride, 2005). Its major principles can be summarized as follows:

(1) A shift should be made from the entrenched power of government bureaucracies to greater responsiveness to citizens via legislative bodies;

(2) Elected political leaders should have greater capacities to manage government (in effect to govern);

(3) Government reliance on rules and procedures should be reduced. There should be more emphasis on performance, "on responsiveness to citizens and accountability for results” (Aucoin, 1995: 3-4).

Various institutional ethnographies from Ontario during the restructuring in the 1980s and early 1990s bring into view the significance of what I'm calling here textual technologies (i.e. technologies built in textual forms that operate to manage and make accountable people's work in institutional settings and, most notably, to supersede the discretionary and trained judgment of professionals). Here are summaries of some of these investigations:

- Standardized procedures for categorizing patients enabling staffing decisions to be made by hospital management rather than by nursing staff were introduced in the 1980s in Ontario (Campbell, 1984). 
- Funding for community colleges pushed them to offer training in competition with private training sources. Established budgetary procedures had not had to account for the profitability of particular programs. Under the new financial regime accounting procedures were introduced enabling such evaluation and subordinating the judgment of departments and instructors to financial administrators (McCoy, 1998; 1999).

- Textual technologies of risk assessment were introduced into the routine assessment of families in child protection work. The technology was intended to ensure that children would be secure even as funding to agencies became based on numbers of clients, hence reducing the time child protection workers could devote to families (Parada, 2002).

- The restructuring of the public school system in Ontario was even more radical (Kerr, 2006), drawing in standardized testing, the publication of school records, the systematic reduction of the power of teachers in the system, the change in status of principals to management, the enlargement of school boards to areas that make it more difficult for teachers to come together; the introduction of an outcomes or performance based standardized curriculum for the province, and so on and so on. The rating of schools was published bringing schools into competition with one another for students.

In all these studies we find a common theme, the introduction of standardizing textual technologies that displace professional decision-procedures and enhance managerial controls.

The restructuring of government has gone further. Managerial strategies and their textual technologies have been adopted and adapted from those that revolutionized corporate management during the 1970s and 80s (Davidow and Malone, 1993). There has been a reorganization of state and public institutions (Saint-Martin, 1998) resulting in what John Clarke and Janet Newton (1996), writing about welfare services in the UK, call the managerial state. They describe the new forms of management that are displacing long-standing regimes of governance in which bureaucracies, governed by rule, allowed little discretion to front-line workers and were complemented by professional forms of organization that assign decision-making discretion to those with specialized training. We can see these kinds of changes in the institutional ethnographies described above. The full development of the managerial state goes further than these, however. Hierarchy becomes a chain of contracts between a higher managerial centre and subordinate units. Plans made by the latter within the general mandate of the unit and the general objectives of government are constituted as contracts; government departments and ministries, the public institutions of health care, post-secondary education, schools and so on, develop 
plans setting targets for which they are accountable (funding will depend on performance as targeted). Those with contracts directly with government may also make internal contracts with departments, divisions, and so on, setting targets for the performance of which they will be accountable. Performance relative to targets can be compared among units of the same category making it possible to set standards across the board and creating, even promoting, competition. Textual technologies (generally developed by firms of consultants) are used to assess performance or outcomes; a circular procedure is established in which measured values corresponding to the rules for setting target performance and outcomes substitute for the actualities of what is going on and what is happening to the people involved. It is particularly powerful at the point of interchange between government and public institutions, and those who are now their 'customers' (i.e. patients, clients, students, parents of school children, and so on).

This circularity is very visible in Janet Rankin's and Marie Campbell's (2006) study of the reorganization of nurses' work under the new public management. They contrast accounts of nurses' work based on Campbell's early 1980s institutional ethnography with Rankin's ethnography completed in 2003. Between these two dates, the new managerialism had been introduced into health care. Their study shows how the primacy of attention to the individual needs of patients is displaced by nurses' responsibility for managerial objectives. Diagnoses are resolved into standardized levels of care and time of bed occupancy; costs are cut by reducing the number and increasing the turnover of beds. Nurses must take responsibility for setting aside the actual conditions and situation of patients in favour of the standardized managerial decision process. For example, patients who will need specialized home care on their release from hospital may be sent home without family members or other resources capable of delivering it. The actualities of their situation that could have formally been incorporated into an extension of their stay is no longer relevant; it does not appear in the standardized system of categories and numerical indicators that evaluate hospital performance. The actualities of individual patients insofar as they are outside the standardized categories do not count.

In practice, and almost incidentally, the managerial state operates a virtual world created as an analogue to the circularities of financial accounting. A business corporation is evaluated in the textual technologies of financial and management accounting that translate what is actually going on where people are at work into monetary terms. The textual technologies of the managerial state adopt and adapt the circularities of business accounting. A higher order frame, often in the form of a contract with the authority to which the unit is accountable, sets the terms, and what will be recognized and measured as performance, output or outcome must be fitted to them (Smith, 2006). What can be recognized as real within the quantified measurements of performance, output or outcomes has an indeterminate relationship to the actualities of people's lives and doings. In Rankin 
and Campbell's (2006) institutional ethnography, we can see just how this managerial reality is both organized in and organizes people's work, while at the same time ensuring that what people come to know in their experience and in the actual local practices of their lives, will not be heard.

I sit with a teacher who is just starting on her professional career in Ontario. She aims to work towards becoming an activist in teachers' unions. We talk about her work; I introduce her to Ann Manicom's (1988) investigation of what teachers' do in the classroom as work that takes time and thought. If the only way of talking about what teachers' do is in the discourse of educators, their actual work and work time disappear from view. My friend can see at once how, if she has to put time in with a few students who present problems for managing the classroom, she has less time to put into teaching the curriculum, including both those students and the remainder of the class who are quietly getting on with their work. Manicom (1988) suggests that how the teacher allocates work time in the classroom makes a difference to the level at which the curriculum is taught to the whole class. But the standardized testing of individual students that now functions to evaluate a school's performance overall and to compare it with others does not take into account the different conditions under which teachers must in practice allocate their work time in class. These are the managerial innovations introduced in Ontario that Lindsay Kerr's (2006) institutional ethnography investigates.

\section{Making Change from Below on the Terrain of the Ruling Relations}

The view I've presented earlier is of a Canadian state that no longer controls a national economy but is oriented at both national and provincial levels to managing territoriallydefined resources and populations in the service of globally organized capital. Though the forms of democracy are real and make a difference, policies and political practices must be oriented to the interests of capital as a condition of citizens' welfare. At the same time, as the managerial state becomes more completely established in government and in how the operation of public institutions is regulated, the circularity of its modes of accountability make them less responsive at the front-line of encounters with citizens as clients, patients, and other recipients of services. Professionals working on the frontline, doctors, teachers, nurses, social workers are, as institutional ethnographers have been discovering, increasingly constrained by the textual technologies that render their performance or the outcomes of their work accountable within the managerial order. Rankin and Campbell's (2006) account of managing nurses' work shows powerfully how responsiveness to the everyday actualities of patient's lives is curtailed.

The new managerial form of governance, whether of government or public institutions in general, is creating an increasingly integrated regime serving the interests of global capital. It is in this context that making change from below becomes of special importance 
in developing alternative and political openings as the current reorganizing closes doors in the ruling relations - which includes the reorganizing of capital. The notion of making change from below offers openings to voices, needs, and interests that are not represented in contemporary regimes of power. It accords with new political realities, particularly when it is joined with recognizing the importance of knowledge of how the ruling relations work and of the ways in which we can intervene to change them.

When George Smith (1990) wrote his well-known paper on activist as ethnographer, he was engaged as an activist in the struggles of gays to turn Canadian government at all levels from an exclusive focus on the prevention of AIDS and palliative care, to treatment. Activism in this mode was activism in the ruling relations; the knowledge gained from activist experience in relation to how government at various levels and the intersecting organization of the medical profession and of health care institutions in general was not of a different order than what he might have learned in an institutional ethnography. As an activist, he was discovering the complex intersections of public health authorities and health departments at the provincial and municipal levels and how government public health policies intervened. AIDS Action Now sought to intervene in these relations and change them. Knowing how they worked meant that Smith knew how, as an activist, to operate in them. His paper is sometimes read as suggesting that we can do without the ethnographer, but he always thought in terms of what is now called institutional ethnography in which indeed he was a pioneer; he was always looking for and working out, how to extrapolate from what he could recognize directly in his work as an activist to an organization of relations of which they are part.

Ian Hussey ${ }^{3}$ and I undertook an institutional ethnography exploring the success of a campaign to establish ethical purchasing as a City of Vancouver policy. ${ }^{4}$ Along the way, I

3 Fair Trade activist and a graduate student at the University of Victoria.

4 This is based on an institutional ethnography undertaken by Ian Hussey and myself. We were working with a program lodged at the University of Guelph called 'Rural Women Making Change' (funded under SSHRC's Community-University Research Alliance program). It is an alliance between community organizations representing rural women's interests in southwest Ontario and academics, most from the University of Guelph, but also involving others from other universities, and myself from the University of Victoria. One of the projects in the program focused on municipalities. (Dr. Susan Turner, coordinator of the program, is a specialist in this area and recognized that there was a lack of knowledge on making change in municipalities.) Ian Hussey had written a paper based on an interview with a local activist in Vancouver on a successful campaign on the part of a coalition of local organizations to establish an Ethical Purchasing Policy in the City of Vancouver. We thought there might be some useful lessons there for how to go about making changes in municipal settings and that Ian and I could produce an account of how it was done, and of the process of implementation that would be useful to efforts in other municipalities to make change from below. So I designed a very modestly funded research program involving seven extensive interviews with key activists, staff and councillors. We also used internet access to public documents and websites of various nongovernmental organizations. 
discovered something quite new to me, though not at all new to the experienced activists involved in it. The story begins with the involvement of the Vancouver and District Labour Council (VDLC) in the success of the Coalition of Progressive Electors (COPE) in winning control of City Council in 2003. Out of this came a coalition, the British Columbia Ethical Purchasing Group involving representatives of other trade unions both local and national, of organizations opposing sweatshops, among them the Maquila Solidarity Network (an organization based in Toronto and connected with labour organization in Mexico and elsewhere), locals of national organizations such as Oxfam Canada and other local branches of national organizations such as Mountain Equipment Co-op, and the Fair Trade Coffee Network. Notice how these organization are formed, act, and build within the ruling relations, and all are at home with modes of political action within them.

In the course of Ian's and my research, we traced the coalition's work of developing a campaign to establish an Ethical Purchasing policy in Vancouver. We learned of other organizations that became implicated in the campaign that did not have local representation but operated only at a national or international level. Complexes of non-governmental organizations are sometimes described as the new or global civil society. I haven't found that concept very useful since it doesn't differentiate among those involved in working for capital and others working for a variety of interests and concerns arising among people in general. It is clear that non-governmental organizations representing the capitalist class proliferate in that general region of the ruling relations and that many organizations that are dedicated to serving people rely partially on government funding under conditions that conform what they do to government objectives $(\mathrm{Ng}, 1986)$. Non-governmental organizations are also regulated under both federal and provincial laws including the tax system. At the same time, our research makes visible two significant aspects of organization within the ruling relations that facilitate change from below.

\section{a) A Division of Political Labour}

There is something that could be described as an emerging division of political labour. In developing the Ethical Purchasing Policy for the City of Vancouver, the International Labour Organization's conventions were brought into play. It is part of the United Nations and Canada is signatory to it. Reference to it and its conventions were used both by activists to help draft the Supplier Code of Conduct (integral to the Ethical Purchasing Policy package) and by City staff to legitimate the labour rules adopted. An organization in the US called Verité was consulted when activists wanted their draft of the Ethical Purchasing policy checked. Verité is a consulting organization specializing in labour issues. There are organizations that certify the fair traded character of a product both internationally and within Canada. These interconnections on the terrain of the ruling relations are no doubt more extensive than those that were brought to our attention. A brief trip on the internet located a number of progressive consulting organizations of lawyers and other professionals - the Progressive Economists Network, for example. 
So there's an emerging division of labour organized in the ruling relations between local political organization aiming at making change at a regional level and organizations that operate, some transnationally, to supply specialized consulting and similar services. Among the service providers, some are run as small businesses, for example, Stratcom, a company in Vancouver and Toronto that does polling, fund-raising and related activities for progressive organizations; others as not-for-profit organizations that are supported by charging for the services they provide. TransFair Canada, for example, certifies Fair Traded products for a fee; others are also not-for-profit organizations that are supported by donations and/or government funding for specific projects.

\section{b) Local Organizing Builds Political 'Capital'}

The concept of making change from below emphasizes local organizing. A campaign draws on and enlivens connections, accumulates activist experience and know-how, but equally important is the building in a particular locality, of further connections, of further experientially developed skills, of experience of involvement in a political process and of the local resources for coalition-building that project beyond a particular political project. The very existence of the BC Ethical Purchasing Group as a coalition and later as members of the City task force responsible for drafting the policy for Council locates the prior involvement of activists in various groups and prior connections among at least some of them. These connections and political experience linked union organization with progressive City councillors as well as with more specialized transnational groups such as Oxfam or the Maquila Solidarity Network and so on. The building of connections, activists' experience and political consciousness among supporters is a vital development in the process of making change from below.

Another example might be that of the passage in the spring of 2007 of minimum wage legislation in the State of Maryland. The campaign had been organized by Progressive Maryland. ${ }^{5}$ Advantage had been taken of the election of a democratic governor. I would guess that Progressive Maryland had been active in his campaign for office. What astonished me when I looked at Progressive Maryland's affiliates was the number and variety of supporting organizations. There were sixty-two in all when I visited the website in July of 2007. As might be expected, many were trade unions or union locals, some identified with specific ethnic groups, but there were also churches or other faithbased groups and local branches of organizations such as the National Association for the Advancement of Colored People (NAACP). The extent of support was impressive. It could not have come about in a moment. I'd read of a successful campaign for the introduction of a minimum wage in Baltimore, Maryland, early in 1994 (Luce, 2004) and there are references on Progressive Maryland's website to two Maryland counties that had already passed minimum wage legislation. There must also have been background work done within religious groups such as the United Church and groups representing ethnic

5 See http://progressivemaryland.org. (Accessed July 23, 2007). 
minorities such as the NAACP.

Progressive Maryland's mobilization of such a range and number of affiliates as well as its success in achieving its minimum wage objectives does not mean the end of its aims and activism. Its website when I visited it listed the issues and campaigns it is working on: public funding of the election campaigns of qualified candidates, increases in investment in public schools, reduction of tuition at post-secondary institutions, closing corporate tax loopholes, supporting a health care expansion demand, and increasing the electoral participation of voters from minorities and 'working families'. ${ }^{6}$ Travelling to Progressive Maryland's website, one finds an 'Action Center' which, in addition to information on how to find your district representative, includes calls for specific actions. At the time of my visit these included supporting the action of a local of the Union of Food and Commercial Workers, contacting a representative telling him to withdraw his support for Bush's veto of legislation that would have increased spending for health care, and other similar locallyoriented actions.

The example of Progressive Maryland suggests some of the possibilities of local organization to make change from below. We might think of making change from below as an ongoing work of organization with multiple foci which expands people's experience of taking action. As with the Women's Movement, organizations form around different interests, but the ability to come together in coalitions aimed at specific objectives and a specific piece of governmental power builds connections and an experience of working together. The emergence of multiple organizations means that a wider range of interests and concerns will be voiced; but that doesn't mean disintegration, as is sometimes argued of the Women's Movement. Rather, it expands the bases of potential organization aimed at making specific changes in a government or public institution around which the interests of a number of organizations and their memberships coalesce and on which action can focus.

I do not want to minimize the significance of unions in representing the interests of workers at the crucial juncture between capital and the production of our subsistence. This becomes more crucial as international unions become effective. Unions have also moved increasingly to build alliances with community organizations to work for objectives in which interests are shared. It's our (mine and Ian's) understanding that the Vancouver Ethical Purchasing campaign got going in part through union initiatives. The BC Ethical Purchasing Group and Progressive Maryland are both examples of effective activist relations between unions and community organizations. Of course, historically unions have developed with a focus on the workplace, the wage, and conditions of work. And when the working class is defined in terms of relations at the workplace, the domestic

6 See http://progressivemaryland.org/page.php?id=145 (Accessed July 23, 2007). 
and other aspects of how people's everyday lives are organized and conditioned extralocally get left out. Central as is the workplace as the point of direct interchange between capital and labour, it does not define a class. Though Davidoff and Hall's (1987) classic study of family fortunes in the eighteenth and early nineteenth centuries focuses on middle-class families, their theoretical innovation is to work with a version of 'class' to which domestic organization is integral. The range of interests and issues identified on Progressive Maryland's websites shows clearly that the inequities of class are multifaceted in contemporary capitalism and that an important aspect of making change from below involves drawing in a range of concerns. Organizations such as Los Angeles's Bus Riders Union $^{7}$ do more, I suspect, for the largely low income bus riders of LA than represent their interests in public transportation - getting more buses, adequate scheduling and so on. Such organizations give those involved a sense of the real possibilities of collective action to make change from below and of themselves as political subjects in more than just this immediate context. In Progressive Maryland's campaigns, the locally experienced interests and concerns of working people are translated not into a consolidated left-wing ideology (Sanbonmatsu, 2004), but into forms of action aimed at concrete objectives. The objectives respond to issues that arise out of people's everyday experience. Progressive Maryland's website 'Action Centre' encourages people to become political subjects and to act. This was an important dimension of the Women's Movement. Women had lacked presence as political subjects; the Women's Movement remade us in the course of becoming active. Progressive Maryland contends with the relative lack of electoral participation among "disenfranchised minorities and working families"; it registers concerns about education and other issues. Connecting into political action, whether indirectly or by direct volunteer participation, transforms problems of people's everyday lives into political objectives and political action, and recognizes individuals as political subjects. The linkages between local issues and problems as people experience them and political objectives can be, and is being, developed in organizing to make change from below. People become engaged, learn from, and discover themselves as political subjects in the course of participating in making change.

\section{Conclusion}

I have written this paper in part as a work of thinking through some of what I've learned from other institutional ethnographers as well as what I learn daily from reading newspapers, listening to the radio (always and only the $\mathrm{CBC}$ ), and reading books that talk to me about what's happening in the world outside my scope of daily news - such as Clarke and Newton's The Managerial State (1997). So this has been a course of discovering what had been emerging for me that I did not yet know how to explicate. The multi-aspectual findings of institutional ethnographers had begun to coalesce into a

7 See Davis (2002).

8 See http://progressivemaryland.org/page.php?id=145 (Accessed July 23, 2007). 
picture of a larger historical trajectory of changes. The restructuring of government as a managerial state may intend greater accountability but as we have migrated through the stories told by institutional ethnographies and have, though briefly, examined the logic of the managerial state, we are looking at shifts in command from multiple dispersed and relatively independent public institutional sites to a centrally coordinated subordination to the interests of capital.

The circularity of the modes in which government and public institutions become accountable are also modes that ensure that accountability will be essentially divorced from the actualities of the everyday lives of those who participate. Though the new public management may have intended to increase the accountability of government to citizens, the circularity of its textual realities means that its management is effectively insulated from the actualities of people's everyday lives, doings, and work. Compared with the regime it displaces, the managerial state exercises more intimate control over public institutions, diminishing the authority and autonomy of the intelligentsia. In this context, making change from below in forms of activist organization that enable people to develop experience, skills, connections and a sense of themselves as political subjects and agents offers possibilities of building from one level of organization to another. Such projects at the local level can connect within the ruling relations with non-governmental organizations operating nationally or transnationally, whose operations complement local organization aimed at specific outcomes.

No magic here. There's no doubt in my mind that the dominance of capital has become increasingly comprehensive. Finding how to make change from below becomes, I believe, a matter of our survival as political subjects in the very general and close-to-home sense of political that was practiced in the women's movement. As we look around at what we are part of and how we participate in the ruling relations, what do we see in the ways in which they are developing? What do we see in the experience of those of us working in universities and colleges as faculty, students or staff? Resistance is often celebrated on the left, but it always remains just that. It doesn't open up questions of how to organize, how to go about making change, or what level of government or institution might be a focus. It may aim at people's political souls but it does not make them political subjects let alone political agents. And I have argued, on the basis of stories of campaigns, that organizing to make change from below builds how-to knowledge, builds connections, builds a knowledge of how the ruling relations are operating and what might be key foci of organizing to make change, and, perhaps most important, it enables people to become active and conscious as political subjects. 


\section{REFERENCES}

Aucoin, P. 1995. The New Public Management: Canada in Comparative Perspective. Montreal: Institute for Research on Public Policy.

Berle, A.A. \& G.C. Means et al. 1932. Modern Corporation and Private Property.

New York: Commerce Clearing House Loose Leaf Service Division of the Corporation Trust Company.

Bobrick, B. 2001. The Making of the English Bible. London: Weidenfeld \& Nicolson.

Campbell, M.L. 1984. Information Systems and Management of Hospital Study in Social Organization of Knowledge. Dissertation: Sociology in Education. Toronto: University of Toronto.

CAUT/ACPPU. 1998. "World Bank Promotes its Agenda in Paris.” Canadian Association of University Teachers/ACPPU Bulletin, Vol. 45, pp 1-2.

Clarke, J. \& J. Newton. 1997. The Managerial State: Power, Politics and Ideology in the Remaking of Social Welfare. London: Sage Publications.

Davidoff, L. \& C. Hall. 1987. Family Fortunes: Men and Women of the English Middle Class, 1780-1850. Chicago, University of Chicago Press.

Davidow, W.H. \& M.S. Malone. 1993. The Virtual Corporation: Structuring and Revitalizing the Corporation for the $21^{\text {st }}$ Century. New York: Harper Collins.

Davis, M. 2002. Dead Cities. New York: The New Press.

Elliott, L. 2007. “The Rich are not Immortal.” The Guardian Weekly, London: 18.

Foster, J. 1974. Class Struggle and the Industrial Revolution. London, Weidenfeld and Nicolson.

Foucault, M. 1972. The Discourse on Language. New York: Pantheon Books.

Habermas, J. 1992. The Structural Transformation of the Public Sphere: An Inquiry Into a Category of Bourgeois Society. Cambridge, MA: The MIT Press.

Kerr, L. 2006. Between Caring and Counting: Teacher's take on Educational Reform. Toronto: University of Toronto Press. 
Lapham, L. 2004. “Tentacles of Rage: the Republican Propaganda Mill, A Brief History." Harpers, No. 309, pp. 31-41.

Luce, S. 2004. Fighting for a Living Wage. Ithaca: Cornell University Press.

Manicom, A. 1988. Constituting Class Relations: The Social Organization of Teachers' Work. Dissertation: Sociology in Education. Toronto: University of Toronto.

Marx, K and F. Engels. 1988. The Communist Manifesto. London: Verso

Marx, K. and F. Engels. 1970. The German Ideology. New York: International Publishers.

McBride, S. 2005. Paradigm Shift: Globalization and the Canadian State. Halifax: Fernwood Press.

McCoy, L. 1999. Accounting Discourse and Textual Practices of Ruling: A Study of Institutional Transformation and Restructuring in Higher Education. Dissertation: Sociology and Equity Studies in Education. Toronto: University of Toronto.

McCoy, L. 1998. "Producing "What Deans Know": Cost-Accounting and the Restructuring of Post-Secondary Education.” Human Studies, Vol. 21: 395-418.

McKeon, M. 1987. The Origins of the English Novel, 1600-1740. Baltimore: Johns Hopkins University Press.

Messer-Davidow, E. 2002. Disciplining Feminism: From Social Action to Academic Discourse. Durham: Duke University Press.

Millett, K. 1970. Sexual Politics. Garden City, NY: Doubleday.

Naples, N. 1997. “The 'New Consensus' on the Gendered 'Social Contract': The 19871988 U.S. Congressional Hearings on Welfare Reform.” Signs: Journal of Women in Culture and Society,Vol.23, No. 4, pp. 907-943.

Ng, R. 1986. The Politics of Community Service: Immigrant Women, Class, and State. Toronto: Garamond. 
Parada, H.U. 2002. The Restructuring of the Child Welfare System in Ontario: A Study in the Social Organization of Knowledge. Dissertation: Sociology and Equity Studies in Education. Toronto: University of Toronto.

Rankin, J.M. and M.L. Campbell 2006. Managing to Nurse: Inside Canada's Health Care Reform. Toronto, University of Toronto Press.

Rose, J. 2002. The Intellectual Life of the British Working Classes. New Haven: Yale University Press.

Saint-Martin, D. 1998. "The New Managerialism and the Policy Influence of Consultants in Government: An Historical-Institutionalist Analysis of Britain, Canada and France.” Governance, Vol. 11, No. 3, pp. 319-355.

Sanbonmatsu, J. 2004. The Postmodern Prince. New York: The Monthly Review Press.

Shapiro, B.J. 2000. A Culture of Fact: England, 1550-1720. Ithaca: Cornell University Press.

Shields, J. \& B.M. Evans. 1998. Shrinking the State: Globalization and Public Administration 'Reform”. Halifax: Fernwood Press.

Smith, D.E. 2006. Institutional Ethnography: A Sociology for People. Lanham: Rowman and Littlefield.

Smith, D.E. 2004. "Ideology, Science and Social Relations: A Reinterpretation of Marx’s Epistemology.” European Journal of Social Theory, Vol. 7, No. 4, pp. 445-462.

Smith, D.E. 1999. The Ruling Relations. Writing the Social: Critique, Theory, and Investigations. Toronto: University of Toronto Press.

Smith, D.E. \& C.F. Schryer. 2007. “On Documentary Society.” In Handbook of Writing Research. C. Bazerman (ed.). New York: Erlbaum.

Smith, G.W. 1990. "Political Activist as Ethnographer." Social Problems, Vol. 37, pp. 401-421.

Smith, G.W. 1988. "Policing the Fay Community: An Inquiry into Textually-Mediated Relations." International Journal of Sociology and the Law, Vol. 16, pp. 401-421. 
Turner, S.M. 2003. The Social Organization of Planning: A Study of Institutional Action as Texts and Work Processes. Dissertation: Sociology \& Equity Studies. Toronto: University of Toronto.

Turner, S.M. 1995. "Rendering the Site Developable: Textual Organization in the Planning Process." In Knowledge, Experience and Ruling Relations: Studies of the Social Organization of Knowledge. M. Campbell and A. Manicom (eds.). Toronto: University of Toronto Press, pp. 234-248.

Walker, G. 1995. "Violence and the Relations of Ruling: Lessons from the Battered Women's Movement. In Knowledge, Experience and Ruling Relations: Studies of the Social Organization of Knowledge. M. Campbell and A. Manicom (eds.). Toronto: University of Toronto Press, pp. 64-79. 